University of Nebraska - Lincoln

DigitalCommons@University of Nebraska - Lincoln

Agronomy \& Horticulture -- Faculty Publications

Agronomy and Horticulture Department

August 2005

\title{
Effects of Summer Grazing Strategies on Organic Reserves and Root Characteristics of Big Bluestem
}

\author{
E. M. Mousel \\ University of Nebraska-Lincoln \\ Walter H. Schacht \\ University of Nebraska-Lincoln, wschacht1@unl.edu \\ C. W. Zanner \\ University of Nebraska-Lincoln, czanner2@unl.edu \\ Lowell E. Moser \\ University of Nebraska-Lincoln, Imoser1@unl.edu
}

Follow this and additional works at: https://digitalcommons.unl.edu/agronomyfacpub

Part of the Plant Sciences Commons

\footnotetext{
Mousel, E. M.; Schacht, Walter H.; Zanner, C. W.; and Moser, Lowell E., "Effects of Summer Grazing Strategies on Organic Reserves and Root Characteristics of Big Bluestem" (2005). Agronomy \& Horticulture -- Faculty Publications. 45.

https://digitalcommons.unl.edu/agronomyfacpub/45
}

This Article is brought to you for free and open access by the Agronomy and Horticulture Department at DigitalCommons@University of Nebraska - Lincoln. It has been accepted for inclusion in Agronomy \& Horticulture -Faculty Publications by an authorized administrator of DigitalCommons@University of Nebraska - Lincoln. 


\title{
Effects of Summer Grazing Strategies on Organic Reserves and Root Characteristics of Big Bluestem
}

\author{
E. M. Mousel,* W. H. Schacht, C. W. Zanner, and L. E. Moser
}

\begin{abstract}
Quantifying root structure response to multiple defoliation events in a grazing situation is critical in developing management plans for warm-season tallgrasses. A pasture experiment was conducted in 1999, 2000, and 2001 near Mead, NE. The objective of the experiment was to determine the effect of timing and frequency of grazing on big bluestem (Andropogon gerardii Vitman) etiolated tiller growth and root and rhizome structure. Paddocks were grazed at a stocking rate of 9.9 Animal Unit Month (AUM) $\mathrm{ha}^{-1}$ in two to four cycles from midMay to early-September. In April 2002, five 6.6- $\times$ 132-cm soil cores were extracted from each paddock. Soil cores were subsampled at 30-cm depth increments for estimates of root mass, root surface area, and root volume. Etiolated tiller tents were used to estimate organic reserves of big bluestem in each paddock in spring 2002. Mean number and weight of etiolated tillers were reduced by up to $40 \%$ and $50 \%$, respectively, in paddocks grazed in a sequence of June after internode elongation, early August, and early September. Root structure in the top $30 \mathrm{~cm}$ of the soil profile was affected most by multiple defoliation events with $<\mathbf{4 0} \mathrm{d}$ of recovery between grazing periods. Root mass decreased by $25 \%$, while mean surface area and volume of roots declined 10 and $15 \%$, respectively, in the upper $30 \mathrm{~cm}$ of the soil profile in paddocks grazed in the sequence of post-internode elongation in June, early-August, and early-September. To maintain vigorous big bluestem pastures, grazing management should concentrate on the elongation and postelongation periods. Grazing at the elongation stage should be rotated among paddocks in successive years and the recovery period following grazing at internode elongation should be $>40 \mathrm{~d}$.
\end{abstract}

$\mathrm{K}$ NOWLEDGE of root and shoot response to defoliation is needed to manage grasslands effectively in environments where water and/or nutrients are limiting (Engel et al., 1998). Quantifying plant responses to defoliation has been the objective of numerous grazing research projects (Belsky, 1986). Most studies have focused on the aboveground shoot response to defoliation even though defoliation reduces root production more than shoot production (Stanton, 1983, Richards, 1984). Even with high nutrient availability in controlled environment conditions, numerous grazing tolerant $\mathrm{C}_{3}$ and $\mathrm{C}_{4}$ forage grasses have demonstrated that root growth essentially ceases within $24 \mathrm{~h}$ after removal of approximately $50 \%$ or more of the shoot system (Crider, 1955; Troughton, 1957, p. 163; Oswalt et al., 1959; Ryle and Powell, 1975). Root mortality and decomposition also may begin within 36 to $48 \mathrm{~h}$ (Oswalt et al., 1959). Following defoliation, there is a rapid reduction in root respiration and nutrient absorp-

Dep. of Agronomy and Horticulture and School of Natural Resources, Univ. of Nebraska-Lincoln, 279 Plant Science, Lincoln, NE 68583. Nebraska Agric. Exp. Stn. Journal Series no. 14832. Received 1 Dec. 2004.*Corresponding author (emousel2@unl.edu).

Published in Crop Sci. 45:2008-2014 (2005).

Forage \& Grazing Lands

doi:10.2135/cropsci2004.0694

(c) Crop Science Society of America

677 S. Segoe Rd., Madison, WI 53711 USA tion (Clement et al., 1978) which may be proportional to the intensity of defoliation (Davidson and Milthorpe, 1966, Thorgeirsson, 1988). The reduction in nutrient absorption following defoliation may, at some levels of intensity, reduce the ability of the plant to reestablish photosynthetic tissues and could jeopardize the overall vigor of the plant (Dawson et al., 2000).

Grazing strategies have been developed to control the timing, intensity, frequency, and selectivity in pastures to obtain the optimal or desired response of the vegetation and grazing animal. Generally, grazing systems are considered desirable if there is minimal impact on plant vigor. Plant vigor is often quantified by the level of available carbohydrate reserves stored in a plant's above-ground and below-ground storage organs for use by defoliated tillers to reestablish photosynthetic tissue (Reece et al., 1997). Few studies, however, have quantified the cumulative effects of grazing strategies on the below-ground components of vegetation in a grazing system. Mousel et al. (2003) identified above-ground vegetation responses to the timing and frequency of grazing big bluestem pasture. The objective of this study is to quantify the cumulative effects of timing and frequency of grazing on root structure and organic reserve estimates in big bluestem pastures.

\section{MATERIALS AND METHODS}

\section{Study Site}

The study was conducted in 1999, 2000, and 2001 at the University of Nebraska Agricultural Research and Develop-

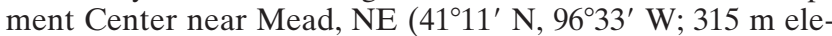
vation). The continental climate of the area is characterized by wide seasonal variations in moisture and air temperature. Average maximum daily temperatures range from $0.1^{\circ} \mathrm{C}$ in January to $31.5^{\circ} \mathrm{C}$ in July. Average minimum daily temperatures range from $-11.4^{\circ} \mathrm{C}$ in January to $18.9^{\circ} \mathrm{C}$ in July. The longterm (1960-2000) average annual precipitation is $65 \mathrm{~cm}$, and about $75 \%$ of this falls during the growing season (April through September) (HPRCC, 2004). The topography varies from level terrain to slopes of less than $3 \%$. The prominent soil at the study site is a Sharpsburg silty clay loam (fine, montmorillonitic, mesic, Typic Argiudoll), and most of the parent material is loess of Peorian age (Elder et al., 1965).

\section{Vegetation}

Vegetation at the study site was a uniform, vigorous stand of 'Pawnee' big bluestem established on a 4-ha field in 1995. The stand was not fertilized during establishment or in subsequent years. Broadleaf weeds were controlled during estab-

Abbreviations: A, early August; AUD, Animal Unit Day (equivalent to $10.5 \mathrm{~kg}$ of forage DM); AUM, Animal Unit Month (equivalent to $310 \mathrm{~kg}$ of forage DM); DM, dry matter; Je, June (elongation); Jv, June (vegetative); M, May grazing; NM, No May grazing; S, early September. 
lishment by applications of 2,4-D (2, 4-dichlorophenoxy acetic acid) at the rate of $2.1 \mathrm{~L} \mathrm{ha}^{-1}$. The stand was not harvested in 1996 and established well, accumulating considerable plant biomass. The site was burned in late April 1999, 2000, and 2001 to remove dead plant material and to create uniform conditions for the grazing trial.

\section{Experimental Methods}

Treatments were arranged in a $2 \times 2 \times 2$ factorial with the following factors and levels: (i) May grazing or no May grazing, (ii) June grazing at a late vegetative stage or June grazing at an early elongation stage, and (iii) late-summer grazing in early August and early September or late summer grazing in September only. The various grazing date treatment combinations were allocated randomly within each of four blocks to eight 0.05-ha paddocks (experimental units). The blocks were arranged within the 4-ha study site with the goal of minimizing stand variability within each block. The four blocks covered 1.6 ha. Each grazing date treatment was applied in a 24-h grazing period. Each paddock had the same grazing treatment applied to it for the $3 \mathrm{yr}$ of the study.

May grazing occurred when the big bluestem was at an early vegetative stage of growth and when tillers were 15 to $20 \mathrm{~cm}$ in height and the paddocks provided about $50 \mathrm{~kg}$ of dry matter per animal unit day (AUD $=10.5 \mathrm{~kg}$ of forage dry matter) of demand. The corresponding dates were 17 May 1999, 31 May 2000, and 21 May 2001. June grazing was designed to either remove a large portion of exposed tiller growing points by grazing at the elongation stage or not remove tiller growing points by grazing at the vegetative stage. The two summer grazing periods (early August and early September) were designed to determine the effect of grazing strategies on herbage availability of big bluestem in late summer, a time when plant recovery from defoliation is slow.

Grazing periods are identified by the following notations: $\mathrm{M}=$ May grazing, $\mathrm{NM}=$ no May grazing, $\mathrm{Jv}=$ June grazing at the vegetative stage, $\mathrm{Je}=$ June grazing at the elongation stage, $\mathrm{A}=$ early-August grazing, and $\mathrm{S}=$ early-September grazing. Each paddock was grazed at a cumulative stocking rate of 9.9 animal unit months (AUM $=310 \mathrm{~kg}$ of forage dry matter) per ha regardless of the number of grazing periods (two to four). This is the recommended stocking rate for big bluestem pasture in eastern Nebraska (Waller et al., 1986). After the initial mid-May grazing period, animal demand was distributed proportionally over the number of grazing periods in each treatment (Table 1). The stocking rate was reduced by $40 \%$ for the early-August and early-September 2001 grazing periods because of dry conditions and low pregrazing yields in mid- to late summer. The grazing animals were Holstein heifers (Bos taurus) weighing between 227 and $454 \mathrm{~kg}$. The wide range of animal weights allowed for application of the designated stocking rate during each grazing period. Between grazing periods, cattle grazed the remaining area (2.4 ha) of the study site and adjacent warm-season grass pastures.

\section{Measurements}

The grazing trial ended at the last sampling period in September 2001. The above-ground response of big bluestem was reported by Mousel et al. (2003). Total organic energy reserves were indirectly estimated (Reece et al., 1997) in each paddock in March 2002. Tents constructed of landscape fabric (Pro5 Weed Barrier, DeWitt Co. Inc., Sikeston, MO) were placed over 10 1.0- $\mathrm{m}^{2}$ areas (Reece et al., 1997) where big bluestem crowns were present in each paddock. At each location, the tents were suspended by two wooden stakes placed $50 \mathrm{~cm}$
Table 1. Experiment treatment combinations and corresponding stocking rates applied in each year by each grazing period.

\begin{tabular}{|c|c|c|c|c|c|}
\hline \multirow[b]{3}{*}{ Treatment $\dagger$} & \multicolumn{5}{|c|}{ Stocking rate by grazing period } \\
\hline & \multirow[b]{2}{*}{ May } & \multicolumn{2}{|c|}{ June } & \multirow{2}{*}{$\begin{array}{c}\text { Early } \\
\text { August }\end{array}$} & \multirow{2}{*}{$\begin{array}{c}\text { Early } \\
\text { September }\end{array}$} \\
\hline & & Vegetative & Elongation & & \\
\hline & & \multicolumn{2}{|c|}{$\mathrm{kg} \mathrm{ha}^{-1}$} & & \\
\hline MJvAS & 2.00 & 2.63 & & 2.63 & 2.63 \\
\hline MJeAS & 2.00 & & 2.63 & 2.63 & 2.63 \\
\hline MJvS & 2.00 & 3.95 & & & 3.95 \\
\hline MJeS & 2.00 & & 3.95 & & 3.95 \\
\hline NMJvAS & 3.30 & 3.30 & & 3.30 & 3.30 \\
\hline NMJeAS & 3.30 & & 3.30 & 3.30 & 3.30 \\
\hline NMJvS & & 4.95 & & & 4.95 \\
\hline NMJeS & & & 4.95 & & 4.95 \\
\hline
\end{tabular}

$\dagger$ Grazing treatment combinations: $\mathbf{M}=$ May; $\mathbf{N M}=$ No May; Jv $=$ June (vegetative); Je = June (elongation); $\mathbf{A}=$ Early August; $\mathbf{S}=$ Early September.

apart and driven to a remaining height of $15 \mathrm{~cm}$. Tents covered an area about $90 \times 90 \mathrm{~cm}$ which provided a 15 -cm-wide buffer around the interior $0.25-\mathrm{m}^{2}$ sample area. Etiolated tillers in the interior $0.25 \mathrm{~m}^{2}$ of each $1.0-\mathrm{m}^{2}$ quadrat were clipped at ground level in May 2002. The clipped tillers from each quadrat were placed in a paper sack and oven dried at $60^{\circ} \mathrm{C}$ for $48 \mathrm{~h}$. Dried tillers were then counted and weighed. In lateApril 2002, before big bluestem emergence from winter dormancy, five soil cores $(6.6 \times 132 \mathrm{~cm})$ were extracted from each paddock in three of the four blocks. Preliminary soil analysis indicated that one block contained heterogeneous soils that were much different from the other three blocks and was excluded from sampling. The soil cores were extracted from the center of a plant using a light truck mounted Giddings soil probe (Fort Collins, $\mathrm{CO}$ ). Each core was wrapped in heavyduty aluminum foil and sealed with tape to prevent excessive drying during transport and storage. Soil cores were stored at $-30^{\circ} \mathrm{C}$ before processing (Oliveira et al., 2000).

Soil cores were thawed at room temperature and cut into four $30-\mathrm{cm}$ sections, discarding the bottom $12 \mathrm{~cm}$ to maintain core length uniformity. Each $30-\mathrm{cm}$ section of core was placed in series of screened sieve boxes with screen size ranging from 3 to $0.1 \mathrm{~mm}$ in descending order and placed in a soaking tank for $24 \mathrm{~h}$. Each section of core was then gently hand washed with water from a garden hose to remove all soil material, leaving only root and rhizome material. Root material extracted from soil cores was then sealed in plastic freezer bags and refrozen at $-30^{\circ} \mathrm{C}$ (Oliveira et al., 2000). Root material was then thawed and scanned for length, surface area, average diameter and volume with a WinRhizo root scanner (Regent Instruments Inc. Quebec). After scanning, roots were dried in a $60^{\circ} \mathrm{C}$ forced-air, drying oven for $48 \mathrm{~h}$. The dried samples were weighed to determine root mass at each depth increment of the soil core.

Rhizomes at the crown of the plant were extracted and separated from root material by manually cutting individual rhizomes from root material. Rhizomes also were scanned with the WinRhizo root scanner. After scanning, rhizomes were dried in a forced-air oven at $60^{\circ} \mathrm{C}$ for $48 \mathrm{~h}$ and then weighed.

\section{Statistical Analysis}

Data for the below-ground response to grazing treatments were analyzed as a stripped split-plot design with four replications. Paddocks were used as the whole plot. Each soil core was the split-plot, and the depth increments of each soil core were the stripped split-plot. Analysis of variance procedures (ANOVA) were conducted by the Statistical Analysis System with the mixed procedure (SAS Inst., 1995; Littell et al., 1996). 


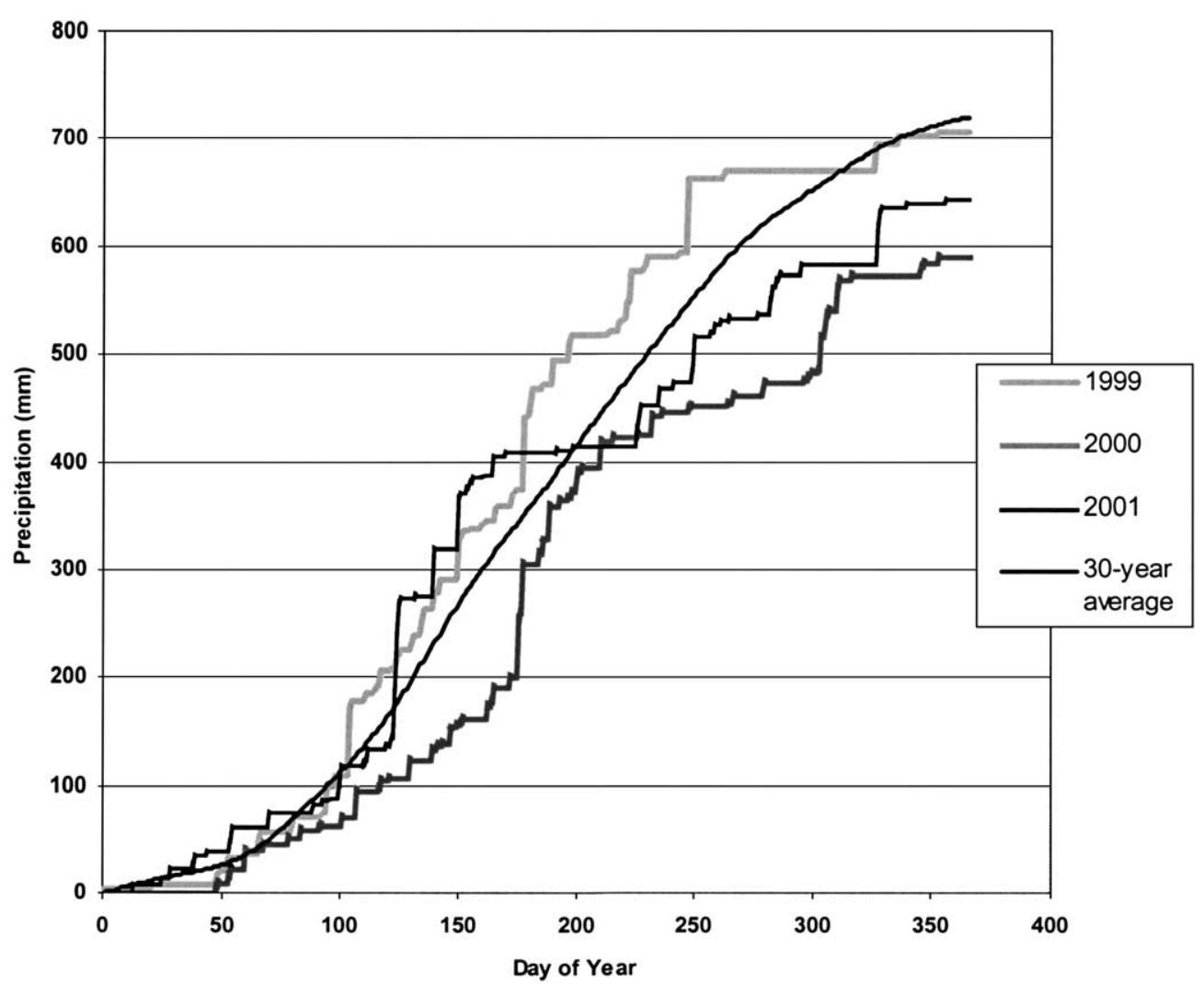

Fig. 1. Accumulated precipitation for the Agricultural Research and Development Center near Mead, NE, for 1999-2001 and the 30-yr average.

Least significant difference (LSD) was used to separate means when ANOVA showed significant $(P<0.1)$ treatment effects.

\section{RESULTS AND DISCUSSION \\ Precipitation}

Accumulated precipitation for the 1999 growing season (May-Oct) was 10\% above average overall (Fig. 1) (HPRCC, 2004). Growing season precipitation in 2000 was $25 \%$ lower than average, although rainfall amounts were relatively high in June and July. Growing season precipitation in 2001 was $10 \%$ above normal for the first half of the growing season and $10 \%$ below normal in the latter half of the growing season resulting in growing season precipitation similar to that of the 30 -yr average for the study site. Temperature regime for the $3 \mathrm{yr}$ was similar to the 30-yr average (HPRCC, 2004).

\section{Total Organic Reserves}

A May grazing period did not affect mean number of etiolated tillers or weight of etiolated tillers. Mean

Table 2. Mean number of etiolated big bluestem tillers per square meter for June and late-summer levels of grazing in 2002 following 3 yr of grazing.

\begin{tabular}{lllll}
\hline & \multicolumn{4}{c}{ June } \\
\cline { 2 - 5 } Late summer & Vegetative & SE & Elongation & SE \\
\cline { 2 - 5 } & & tillers $\mathbf{m}^{-2}$ & \\
September & $\mathbf{2 8 0 a A} \dagger$ & 24.6 & $\mathbf{2 5 5 a A}$ & $\mathbf{2 4 . 4}$ \\
August, September & $\mathbf{3 0 5 a A}$ & $\mathbf{2 4 . 4}$ & $\mathbf{1 6 5 b B}$ & $\mathbf{2 4 . 6}$ \\
\hline
\end{tabular}

$\dagger$ Means with same lowercase letter are not different $(P>0.1)$ within row. Means with same uppercase letter are not different $(P>0.1)$ within column. number of etiolated tillers in paddocks grazed at JeAS were 35 and $45 \%$ less $(P<0.1)$ than paddocks grazed at JeS and JvAS, respectively (Table 2). Total weight of etiolated tillers in paddocks grazed at JeAS was 46 and $52 \%$ less $(P<0.1)$ than paddocks grazed at JeS and JvAS, respectively (Table 3 ). The weight and number of etiolated tillers in paddocks grazed at JvS did not differ from the JeS and JvAS paddocks. The JeAS paddocks also were characterized by low above-ground productivity and stand persistence (Mousel et al., 2003). Intensive clipping of big bluestem for even $1 \mathrm{yr}$ can decrease rhizome nitrogen and total nonstructural carbohydrates in the subsequent season (Owensby et al., 1974). Defoliation tolerance in rhizomatous species generally begins to decrease rapidly following internode elongation (Richards and Caldwell, 1985; Busso et al., 1990) and when tiller densities are at a seasonal low (Hull, 1987). The decrease in regrowth potential following internode elongation may be a result of a loss of active shoot meristems and slow development of new basal tillers (Branson,

Table 3. Mean tiller weight of etiolated big bluestem tillers $\left(\mathrm{g} \mathrm{m}^{-2}\right)$ for June and late-summer levels of grazing in 2002 following 3 yr of grazing.

\begin{tabular}{|c|c|c|c|c|}
\hline \multirow[b]{2}{*}{ Late summer } & \multicolumn{4}{|c|}{ June } \\
\hline & Vegetative & SE & Elongation & SE \\
\hline \multirow{3}{*}{$\begin{array}{l}\text { September } \\
\text { August, September }\end{array}$} & & - & & \\
\hline & $18.5 \mathrm{aA} \dagger$ & 1.23 & $17.5 \mathrm{aA}$ & 1.22 \\
\hline & 19.5aA & 1.22 & $9.5 \mathrm{bB}$ & 1.23 \\
\hline
\end{tabular}

$\dagger$ Means with same lowercase letter are not different $(P>0.1)$ within row. Means with same uppercase letter are not different $(P>0.1)$ within column. 


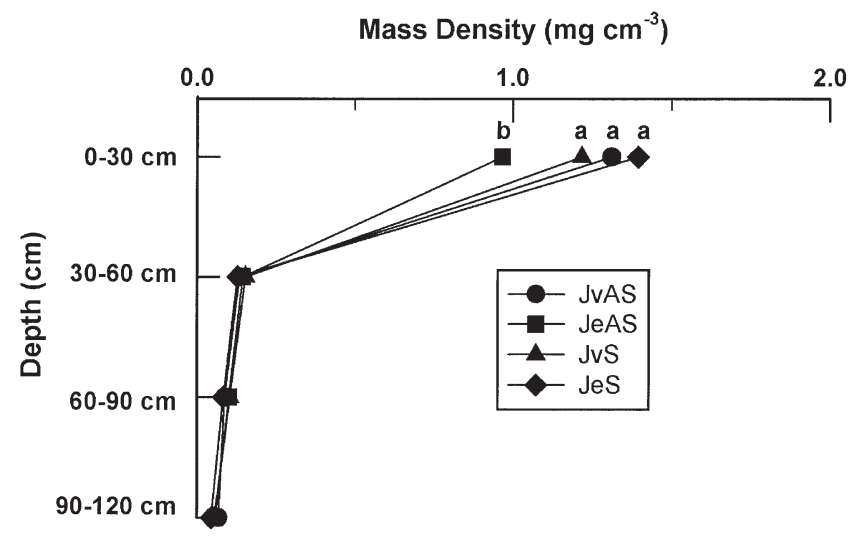

Fig. 2. Mean root mass-density $\left(\mathrm{mg} \mathrm{cm}^{-3}\right)$ of big bluestem for June and late-summer levels of grazing averaged over both levels of May grazing in $\mathbf{2 0 0 2}$ following 3 yr of grazing.

1953; Olson and Richards, 1988). Moreover, recovery may be delayed in situations where multiple defoliation events are imposed within a relatively short period of time, especially when optimal growing conditions are quickly declining (Muldoon and Pearson, 1979; Richards and Caldwell, 1985; Gerrish et al., 1994; Mousel et al., 2003). In our study, recovery periods were relatively short $(<40 \mathrm{~d})$ in the JeAS sequence and moisture conditions and daylength were declining from late June through August. Leaf area development following two or more grazing events at this time may be delayed by inadequate carbon assimilates to initiate axillary buds and supply assimilates for new shoot growth, which may severely limit carbon uptake. A reduction in uptake and assimilation of carbon substrates could reduce carbon availability for root growth and organic reserve accumulation (Miller and Rose, 1992; Thornton et al., 2000).

\section{Roots and Rhizomes}

\section{Depth Increments}

There were no differences among treatments at depth increments below $30 \mathrm{~cm}$ in root mass density, root surface area density, and root volume density. However, an inverse relationship existed in big bluestem between soil depth increment and root characteristics where

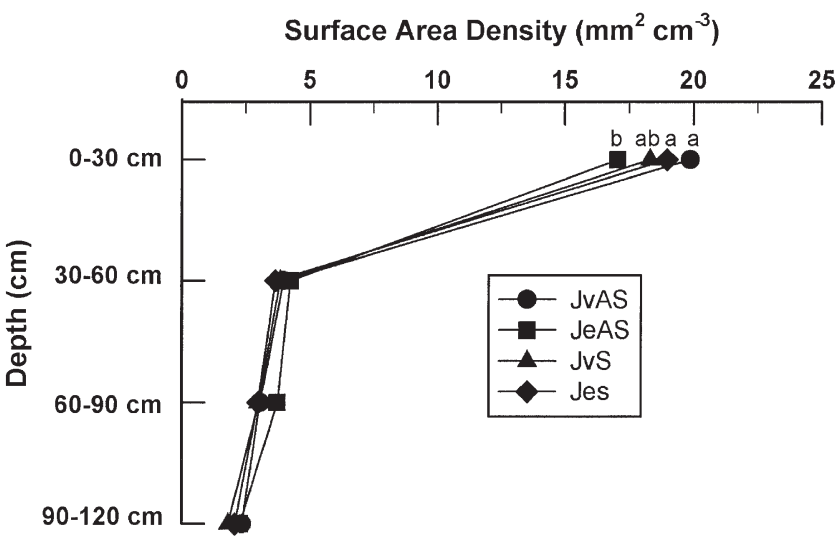

Fig. 3. Mean surface area-density $\left(\mathrm{mm}^{2} \mathrm{~cm}^{-3}\right)$ of big bluestem roots for June and late-summer levels of grazing averaged over both levels of May grazing in 2002 following $3 \mathrm{yr}$ of grazing.

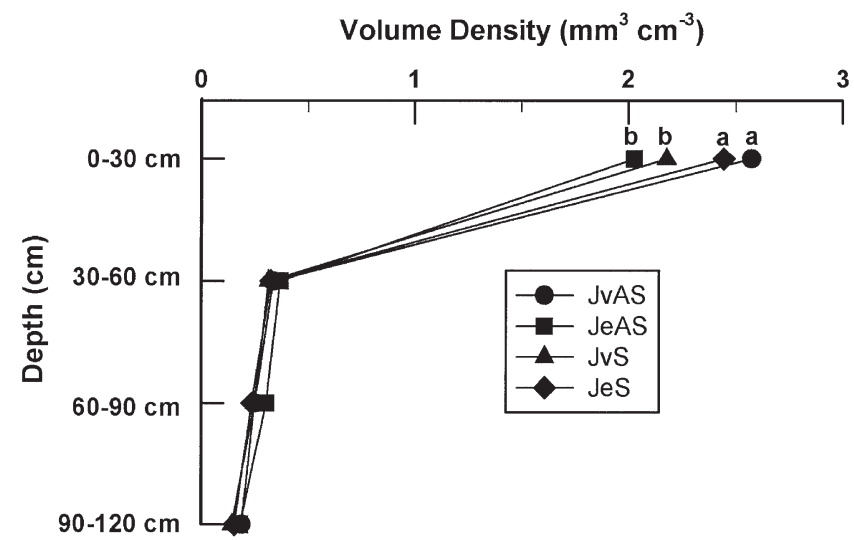

Fig. 4. Mean root volume-density $\left(\mathrm{mm}^{3} \mathrm{~cm}^{-3}\right)$ of big bluestem for June and late-summer levels of grazing averaged over both levels of May grazing in 2002 following $3 \mathrm{yr}$ of grazing.

mass density, surface area density, and volume density of big bluestem roots decreased $(P<0.1)$ as soil depth increased.

\section{Structure}

Root mass density, surface area density, and volume density in the top $30 \mathrm{~cm}$ of the soil profile generally were not affected by a May grazing period but were lowest $(P<0.1)$ in paddocks grazed JeAS (Fig. 2, 3, and 4). Similar results have been reported for multiple, late summer defoliation events in sand bluestem (Andropogon hallii Hack.) (Engel et al., 1998), 'Hycrest' crested wheatgrass (Agropyron desertorum Fisch. Ex Link Schult. $\times$ Agropyron cristatum L. Gaert.) (Arredondo and Johnson, 1998), and Danthonia linkii Kunth (Harradine and Whalley, 1981). Root length also was reported to be sensitive to defoliation and likely is the principal factor affecting root volume of grasses (Harradine and Whalley, 1981, Arredondo and Johnson, 1998, Engel et al., 1998). In general, root diameter is reduced by repeated defoliation (Evans, 1971; Chapin and Slack, 1979; Chapin, 1980). In this study, root diameter rather than root length was the key variable influencing root volume density of big bluestem (Fig. 5), as root lengths were not different $(P>0.1)$ among treatments. Rhizome mass density of big bluestem also was impacted by timing and frequency

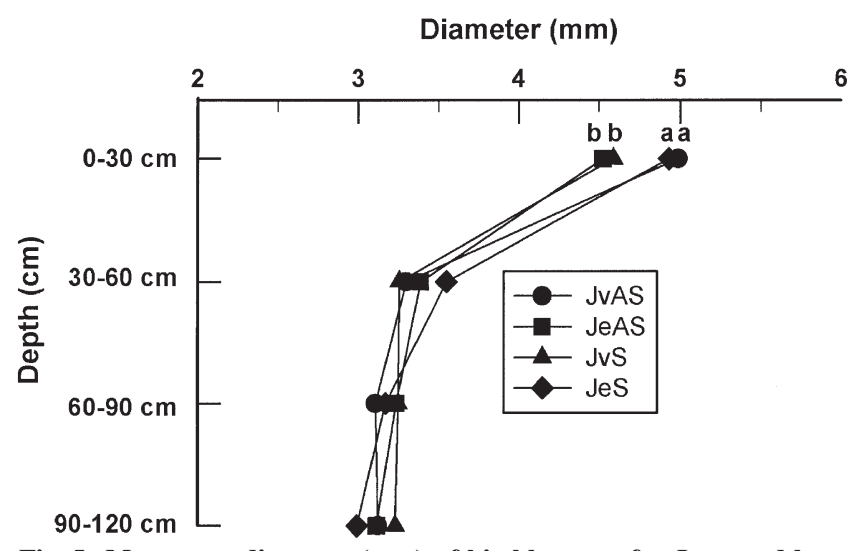

Fig. 5. Mean root diameter ( $\mathrm{mm}$ ) of big bluestem for June and latesummer levels of grazing averaged over both levels of May grazing in 2002 following 3 yr of grazing. 
Table 4. Mean mass of big bluestem rhizomes for June and latesummer levels of grazing in 2002 following 3 yr of grazing.

\begin{tabular}{|c|c|c|c|c|}
\hline \multirow[b]{2}{*}{ Late summer } & \multicolumn{4}{|c|}{ June } \\
\hline & Vegetative & SE & Elongation & SE \\
\hline & & & & \\
\hline $\begin{array}{l}\text { September } \\
\text { August, September }\end{array}$ & $\begin{array}{l}\text { 4.5aA } \dagger \\
4.5 \mathrm{aA}\end{array}$ & $\begin{array}{l}0.84 \\
0.74\end{array}$ & $\begin{array}{l}4.6 \mathrm{aA} \\
3.2 \mathrm{bB}\end{array}$ & $\begin{array}{l}0.86 \\
0.85\end{array}$ \\
\hline
\end{tabular}

$\dagger$ Means with same lowercase letter are not different $(P>0.1)$ within row. Means with same uppercase letter are not different $(P>0.1)$ within column.

of grazing. Big bluestem plants grazed at JeAS had about $30 \%$ less $(P<0.1)$ rhizome mass density than plants in paddocks grazed at JvS, JvAS, and JeS (Table 4).

As stated earlier, a grazing period in late-June after internode elongation likely removed a large portion of big bluestem apical meristems and stimulated new tiller development. The subsequent growth from axillary buds may have been energetically expensive for big bluestem plants requiring a shift in carbon allocation to fuel new shoot growth. Several studies (Oswalt et al., 1959; Davidson and Milthorpe, 1965; Richards, 1984) have indicated that defoliation may result in reduced root growth rate or even complete cessation of root extension and nutrient uptake in plants. Crider (1955) also found that defoliation of tomato (Lycopersicon esculentum Mill.), cabbage (Brassica oleracea L.), peach (Prunus sp. L.), plum (Prunus sp. L.), and pine seedlings (Pinus sp.) resulted in cessation of root function in all species. These findings imply a shift in carbon allocation patterns away from root structures as well. With a reduction or cessation of root growth, the soil solution may become depleted of labile nutrients in areas around existing root structures, especially in areas where water is limiting (Drew, 1975, 1987; Granato and Raper, 1989). Failure of the plant (as a result of defoliation stress) to allocate resources for additional roots to explore for new pools of nutrients in the soil solution (Salisbury and Ross, 1992) could result in malnutrition of the plant if repeated defoliation events occur. Root responses to defoliation after internode elongation may be further magnified by successive late-summer defoliation events, especially if adequate recovery time $(>40 \mathrm{~d})$ is not allowed between events. These results correspond with the low weight and number of

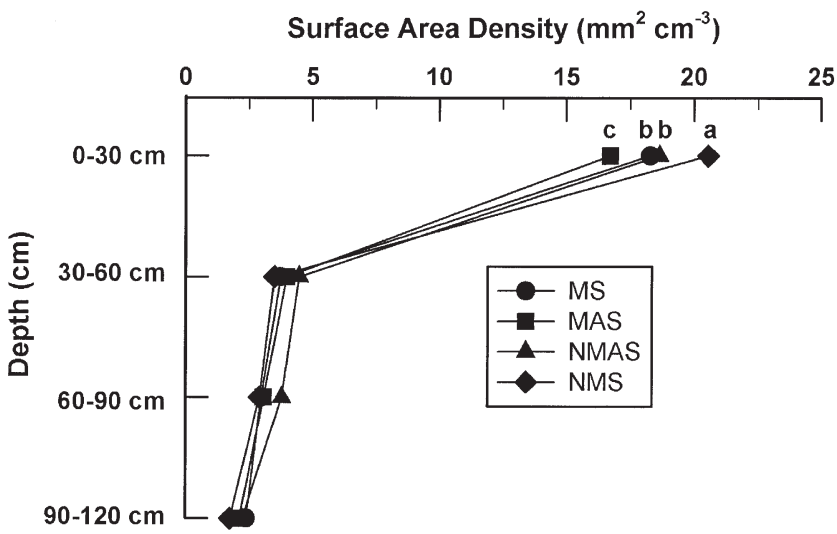

Fig. 6. Mean surface area-density $\left(\mathrm{mm}^{2} \mathrm{~cm}^{-3}\right)$ of big bluestem roots for May and late-summer levels of grazing averaged over both levels of June grazing in 2002 following 3 yr of grazing.

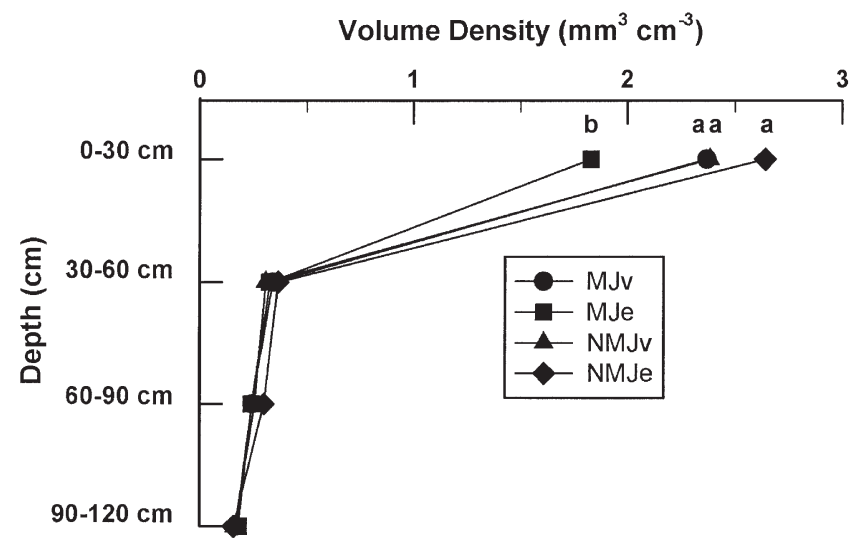

Fig. 7. Mean root volume-density $\left(\mathrm{mm}^{3} \mathrm{~cm}^{-3}\right)$ of big bluestem for May and June levels of grazing averaged over both levels of late summer grazing in 2002 following 3 yr of grazing.

etiolated tillers reported earlier and agree with the low stand productivity and persistence in JeAS grazed paddocks (Mousel et al., 2003).

Surface area density of roots in the top $30 \mathrm{~cm}$ of paddocks grazed in May, at either level of June, and in early August and early September (MAS) was less $(P<$ $0.1)$ than in paddocks grazed NMAS, NMS, and MS (Fig. 6). Surface area density of roots in paddocks not grazed in May, grazed at either level of June, and grazed in early September (NMS) was greater $(P<0.1)$ than in paddocks grazed NMAS, MAS, and MS. The NMS paddocks were grazed only twice during the growing season; all other paddocks were grazed three to four times during the growing season. Reductions in root surface area density appeared to be closely related to number of grazing periods and length of recovery intervals between grazing periods within a growing season. Although two grazing periods with a recovery interval of $>75 \mathrm{~d}$ in late summer did not appear to affect surface area density of roots, three or more grazing periods with a recovery interval of $<40 \mathrm{~d}$ in late summer may cause reductions in root surface area density as indicated in JeAS paddocks earlier.

Root diameter and subsequent root volume density of big bluestem in the top $30 \mathrm{~cm}$ of the soil profile in paddocks grazed MJe were less $(P<0.1)$ than in paddocks grazed MJv, NMJv, and NMJe (Fig. 7 and 8). Al-

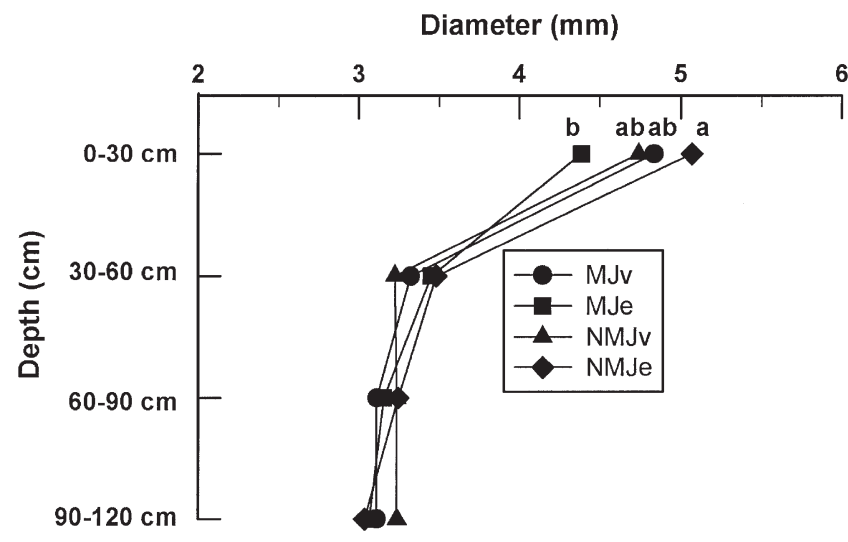

Fig. 8. Mean root diameter ( $\mathrm{mm}$ ) of big bluestem for May and June levels of grazing averaged over both levels of late summer grazing in 2002 following $3 \mathrm{yr}$ of grazing. 
though the MJe interaction effect had a negligible effect on above ground vegetation response over the $3 \mathrm{yr}$ (Mousel et al., 2003), defoliation effects on roots may be precursory to effects on above-ground production over the long term (Jameson, 1963; Stanton, 1983; and Richards, 1984). Root volume density of big bluestem in the top $30 \mathrm{~cm}$ of the soil profile was not affected by a May grazing period; however, root volume density in paddocks grazed JvS was not different from JeAS and was less $(P<0.1)$ than in paddocks grazed JvAS and JeS (Fig. 4). Explanations for the low root volume density in the JeAS paddocks have been discussed already, but the reasons for the low root volume density in the JvS paddocks are not apparent.

Herbage yields and persistence of big bluestem pastures tend to be negatively affected by management strategies employing multiple, frequent $(<40 \mathrm{~d})$ defoliation events late in the growing season after grazing at internode elongation in June (Forwood and Magai, 1992; Gerrish et al., 1994; Mousel et al., 2003). Results from our study indicate that this type of grazing management results in a reduction of organic reserves, root and rhizome mass density, root surface area density, and root volume density. Reductions in below-ground structures possibly restrict a plant's ability to compete effectively with neighboring plants and may delay restoration of photosynthetic capacity following defoliation. Defoliation events in the second half of the growing season may restrict a plant's ability to acquire and store carbohydrates for winter survival and initial spring growth, affecting overall plant vigor, especially if the prevailing late summer conditions are limiting in moisture (Anderson and Matches, 1983). Although number of grazing cycles appeared to have an impact on root surface area density, it likely affected root structure and plant vigor less than the timing of each individual defoliation event and recovery period length within the overall grazing strategy. Big bluestem plants in paddocks grazed in May or June with early-season recovery periods of 20 to $30 \mathrm{~d}$ and late-season recovery periods of 40 to $50 \mathrm{~d}$ displayed similar root structure characteristics and levels of plant vigor. These data in combination with Mousel et al. (2003) suggests that grazing strategies for warm-season tallgrass pastures should focus on timing of defoliation events while maintaining adequate recovery intervals between grazing periods. Furthermore, multiple late-season defoliation events after grazing at internode elongation in June should be avoided in successive years.

\section{REFERENCES}

Anderson, B., and A.G. Matches. 1983. Forage yield, quality and persistence of switchgrass and Caucasian bluestem. Agron. J. 75: $119-124$.

Arredondo, J.T., and D.A. Johnson. 1998. Clipping effects on root architecture and morphology of 3 range grasses. J. Range Manage. 51:207-214.

Belsky, A.J. 1986. Does herbivory benefit plants? A review of the evidence. Am. Nat. 127:870-892.

Branson, F.A. 1953. Two new factors affecting resistance of grasses to grazing. J. Range Manage. 6:165-171.

Busso, C.A., J.H. Richards, and N.J. Chatterton. 1990. Nonstructural carbohydrates and spring regrowth of two cool-season grasses: Interaction of drought and clipping. J. Range Manage. 43:336-343.
Chapin, F.S. 1980. The mineral nutrition of wild plants. Annu. Rev. Ecol. Syst. 11:233-260.

Chapin, F.S., and M. Slack. 1979. Effect of defoliation upon root growth, phosphate absorption and respiration in nutrient-limited tundra graminoids. Oecologia 79:551-557.

Clement, C.R., M.J. Hopper, L.H.P. Jones, and E.L. Leafe. 1978. The uptake of nitrate by Lolium perenne from flowing nutrient solution: II. Effect of light, defoliation, and relationship to $\mathrm{CO}_{2}$ flux. J. Exp. Bot. 29:1173-1183.

Crider, F.J. 1955. Root-growth stoppage resulting from defoliation of grass. USDA Tech. Bull. 1102. U.S. Gov. Print. Office, Washington, DC.

Dawson, L.A., S.J. Grayston, and E. Paterson. 2000. Effects of grazing on the roots and rhizosphere of grasses. p. 61-84. In G. Lemaire et al. (ed.) Grassland ecophysiology and grazing ecology. CABI Publishing, New York.

Davidson, J.L., and F.L. Milthorpe. 1965. The effects of defoliation on the carbon balance in Dactylis glomerata. Ann. Bot. 30:185-198.

Davidson, J.L., and F.L. Milthorpe. 1966. Leaf growth in Dactylis glomerata following defoliation. Ann. Bot. 30:173-184.

Drew, M.C. 1975. Comparison of the effects of a localized supply of phosphate, nitrate, ammonium, and potassium on the growth of the seminal root system, and the shoot, in barley. New Phytol. 75:479-490.

Drew, M.C. 1987. Function of root tissues in nutrient and water transport. p. 71-101. In J. Gregory et al. (ed.) Root development and function-Effects of the physical environment. Cambridge University Press, Cambridge, England.

Elder, J.A., T.E. Beesley, and W.E. McKinzie. 1965. Soil survey of Saunders County, Nebraska. USDA Soil Conserv. Serv. Washington, DC

Engel, R.K., J.T. Nichols, J.L. Dodd, and J.E. Brummer. 1998. Root and shoot response of sand bluestem to defoliation. J. Range Manage. 51:1, 42-46.

Evans, P.S. 1971. Root growth of Lolium perenne L. II. Effects of defoliation and shading. N. Z. J. Agric. Res. 14:552-562.

Forwood, J.R., and M.M. Magai. 1992. Clipping frequency and intensity effects on big bluestem yield, quality, and persistence. J. Range Manage. 45:554-559.

Gerrish, J.R., P.R. Peterson, F.A. Martz, and R.E. Morrow. 1994. Impact of grazing management on production and persistence of big bluestem pastures. 299-303. In Proc. Forage Grassl. Counc., Lancaster, PA. 6-10 Mar. 1994. Am. Forage Grassl. Counc., Georgetown, TX.

Granato, T.C., and C.D. Raper, Jr. 1989. Proliferation of maize (Zea mays L.) roots in response to localized supply of nitrate. J. Exp. Bot. 40:263-275.

Harradine, A.R., and R.D.B. Whalley. 1981. A comparison of the root growth, root morphology and root response to defoliation of Aristida ramose R.Br. and Danthonia linkii Kunth. Aust. J. Agric. Res. 32:565-574.

High Plains Regional Climate Center (HPRCC). 2004. Climatological data (Nebraska). HPRCC, Lincoln, NE.

Hull, R.J. 1987. Kentucky bluegrass photosynthate partitioning following scheduled mowing. J. Am. Soc. Hortic. Sci. 112:829-834.

Jameson, D.A. 1963. Responses of individual plants to harvesting. Bot. Rev. 29:532-594.

Littell, R.C., G.A. Miliken, W.W. Stroup, and R.D. Wolfinger. 1996. SAS system for mixed models. SAS Inst. Cary, NC.

Miller, R.F., and J.A. Rose. 1992. Growth and carbon allocation of Agropyron desertorum following autumn defoliation. Oecologia 89:482-486.

Mousel, E.M., W.H. Schacht, and L.E. Moser. 2003. Summer grazing strategies following early-season grazing of big bluestem. Agron. J. 95:1240-1245.

Muldoon, D.K., and C.J. Pearson. 1979. Morphology and physiology of regrowth of the tropical tallgrass hybrid Pennisetum. Ann. Bot. 43:719-728.

Oliveira, M.R.G., M. van Noordwijk, S.R. Gaze, G. Brouwer, S. Bona, G. Mosca, and K. Hairiah. 2000. Auger sampling, ingrowth cores and pinboard methods. In A.L. Smit et al. (ed.) Root methods. Springer-Verlag, Berlin.

Olson, B.E., and J.H. Richards. 1988. Tussock regrowth after grazing: 
Intercalary meristem and axillary bud activity of Agropyron desertorum. Oikos 51:374-382.

Oswalt, D.L., A.R. Bertrand, and M.R. Teel. 1959. Influence of nitrogen fertilization and clipping on grass roots. Soil Sci. Soc. Am. Proc. 23:228-230.

Owensby, C.E., J.R. Rains, and J.D. McKendrick. 1974. Effects of one year of intensive clipping on big bluestem. J. Range Manage. 27:341-343

Reece, P.E., J.T. Nichols, J.E. Brummer, and R.K. Engel. 1997. Technical note: Field measurement of etiolated tiller growth of rhizomatous grasses. J. Range Manage. 50:175-177.

Richards, J.H. 1984. Root growth response to defoliation in two Agropyron bunchgrasses: Field observations with an improved periscope. Oecologia 64:21-25.

Richards, J.H., and M.M. Caldwell. 1985. Soluable carbohydrates, concurrent photosynthesis and efficiency in regrowth following defoliation: A field study with Agropyron species. J. Appl. Ecol. 22:907-920.

Ryle, G.J., and C.E. Powell. 1975. Defoliation and regrowth in the graminaceous plant: The role of current assimilate. Ann. Bot. 39: 297-310.
Salisbury, F.B., and C.W. Ross. 1992. Plant physiology. 4th ed. Wadsworth Publishing Co. Belmont, CA.

SAS Institute. 1995. SAS/STAT user's guide. Version 6. SAS Inst. Cary, NC.

Stanton, N.L. 1983. The effect of clipping and photophagous nematodes on net primary production of blue grama, Bouteloua gracilis. Oikos 40:249-257.

Thorgeirsson, H. 1988. The modeling and measurement of respiratory carbon use and net carbon gain of two Agropyron bunchgrasses. Ph.D. Diss., Utah State University, Logan.

Thornton, B., P. Millard, and U. Bausenwein. 2000. Reserve formation and recycling of carbon and nitrogen during regrowth of defoliated plants. p. 85-100. In G. Lemaire et al. (ed.) Grassland ecophysiology and grazing ecology. CABI Publishing, New York.

Troughton, A. 1957. The underground organs of herbage grasses. Commonwealth Bureau of Pastures and Field Crops, Bull. 44. Commonwealth Bureau of Pastures and Field Crops, Hurley, Berkshire, England.

Waller, S.S., L.E. Moser, and B. Anderson. 1986. A guide for planning and analyzing a year-round forage program. EC 86-113-C. Nebraska Coop. Ext. Univ. of Nebraska, Lincoln, NE. 